Article

\title{
Sustainability Inclusion in Informatics Curriculum Development
}

\author{
Deepti Mishra ${ }^{1, *(\mathbb{D})}$ and Alok Mishra ${ }^{2,3}$ (1) \\ 1 Department of Computer Science, NTNU—Norwegian University of Science and Technology, \\ 2815 Gjøvik, Norway \\ 2 Faculty of Logistics, Molde University College-Specialized University in Logistics, 6410 Molde, Norway; \\ alok.mishra@himolde.no \\ 3 Department of Software Engineering, Atilim University, 06830 Ankara, Turkey \\ * Correspondence: deepti.mishra@ntnu.no
}

Received: 15 May 2020; Accepted: 11 July 2020; Published: 17 July 2020

check for updates

\begin{abstract}
Background: Presently, sustainability is a crucial issue for human beings due to many disasters owing to climate change. Information Technology (IT) is now part of everyday life in society due to the proliferation of gadgets such as mobile phones, apps, computers, information systems, web-based systems, etc. (2) Methods: The analysis is based on recent ACM/IEEE curriculum guidelines for IT, a rigorous literature review as well as various viewpoints and their relevance for sustainability-oriented curriculum development; it also includes an assessment of key competencies in sustainability for proposed units in the IT curriculum. (3) Results: Sustainability is a critical subject for prospective IT professionals. Therefore, it is imperative to motivate and raise awareness among students and the faculty community regarding sustainability through its inclusion in the Informatics curriculum. This paper focuses on how sustainability can be included in various courses of the Informatics curriculum. It also considers recent ACM/IEEE curriculum guidelines for IT professionals, which assert that IT students should explore IT strategies required for developing a culture of green and sustainable IT. (4) Conclusions: This paper provides guidelines for IT curriculum development by incorporating sustainable elements in courses, so that future IT professionals can learn and practice sustainability in order to develop a sustainable society.
\end{abstract}

Keywords: curricula; environment; information technology (IT); informatics; sustainability

\section{Introduction}

Sustainability is becoming a crucial concern in information technology regarding our future. Sustainable development seeks to meet the needs and aspirations of the present without compromising the ability of future generations to meet their own needs [1]. Initially, four dimensions of sustainability were introduced: individual/human, social equity, economic development, and environmental protection [2,3]. These are interrelated and should be selected in a manner towards an optimum arrangement and alliance. Nolin [4] argued that these dimensions of sustainable development may be incomplete from an information and communication technology (ICT) perspective and should perhaps be joined by a technological dimension. He further explained that without a clear technological dimension of sustainable development, it becomes difficult to package ideas and strategies in such a way that they are clearly linked to other dimensions. Engineers tend to focus on the technical dimension of sustainability [5]. The technical dimension covers the ability to maintain and evolve systems over time, which involves maintenance and evolution, resilience, and the ease of system transitions [6]. However, changes in one system, in one dimension, often have impacts on other dimensions and other systems, e.g., a difficulty in maintaining systems' excessive maintenance costs affects their company's 
financial liquidity (social and economic sustainability), which might limit its growth and even threaten its survival (economic sustainability) [5].

The United Nations Agenda 2030 for sustainable development lays out the global and local challenges mankind is facing, with a view to the needed transformation toward sustainable development [7]. As information plays an important role in development, information scientists should be included in this debate [8]. Several international and national policy documents have recognized the importance of management, access, use, and sharing of data and information for sustainable development [9]. IT now plays a crucially important role in the environmental and energy fields [10]. Chowdhury [11] argued that sustainability should become a mainstream research topic within information studies, since information forms an integral part of every development and innovation.

"Informatics is the science of information. It studies the representation, processing, and communication of information in natural and artificial systems. Since computers, individuals and organizations all process information, informatics has computational, cognitive and social aspects" [12]. The author of this study further states that informatics used in conjunction with the name of a discipline, such as medical informatics or bio-informatics, denotes the specialization of informatics in the management and processing of data, information, and knowledge in the named discipline [12]. Sustainability is interpreted as the capacity of a socio-technical system to endure [5]. It is a systemic concept, as sustainability dimensions (social, individual, environmental, economic, and technical) are interwoven with the functions and constraints of any given socio-technical system, mutually interdependent, and contextualized by the ethical and legal norms and social practices [13]. Sustainable IT is defined as the application of IT practices and technologies for the benefit of customers and other stakeholders, ensuring long-term well-being in the economic, social, and environmental sustainability pillars [14]. Therefore, one of the goals of sustainable IT education is to inculcate awareness, appreciation, and the practice of sustainable IT in professional life, as supported by another study: the design, manufacture, use, and disposal of IT equipment to improve performance and system use while ensuring economic viability, maintained by social and business ethical responsibilities [15]. Although sustainability has often been equated with environmental issues, it is evident that it requires the simultaneous consideration of environmental resources, societal and individual well-being, economic prosperity, and the long-term viability of technical infrastructure [5].

Informatics has become an integral part of our everyday life, gradually impacting human beings and society. Sustainability management is one of the upcoming movements of the 21st century, but, until now, it did not get as much attention as it should have by the informatics community. Organizations are now beginning to understand that not only cost-efficiency, but also long-term and continued prosperity can be gained from sustainability. Therefore, apart from factors like cost, time, and quality, sustainability has also become one of the significant objectives to achieve when developing, configuring, operating, and implementing information systems.

Educational institutions can play a pivotal role in training the younger generation to address this critical issue. Shapiro [16] observed that universities have multiple roles in society: one is to serve the existing society and the other is to challenge society to shape a better future. Education is responsible for promoting the right types of key professional skills for sustainability (KPSS), that will lead to sustainable and inclusive growth and to a peaceful life for all individuals [17]. It should be ensured that all learners acquire the knowledge and skills through education to promote sustainable development. Sustainable data and information practices can be promoted through education and training [9]. Institutions should be required to integrate sustainable development into their educational programs for information professionals and to communicate to future professionals their role in building tomorrow's sustainable society [4]. Yet, there is no mention of sustainability in our existing statutory science curriculum [18]. Many higher education institutes still focus more on the greening of their campus rather than on integrating and infusing sustainability into the curriculum [19]. 
Researchers have noticed that sustainability is under-represented in the curricula [20]. It is crucial to introduce environmental and social perspectives in the curricula of future graduates [21], also known as "sustainable curricula" [22]. Technical faculties and universities are particularly prone to barriers to change concerning sustainability [23]. Most of the efforts to reform engineering curricula to include sustainable development have been primarily focused on developing individual courses on sustainability despite the need for broad curriculum reform [24], rather than integrating sustainability concepts into existing courses in the curricula. Hence, there is a need to include the concept of sustainability in the university curriculum of informatics and IT courses. However, there is no clear consensus on the definition or the list of desired competencies, skills, or learning outcomes in engineering education for sustainable development [25]. Despite long-standing calls [26], computing education has been slow to act on the inclusion of sustainability and of knowledge on how the existing basic software engineering theory and practice relate to sustainability [27]. Penzenstadler et al. [28] noticed that, due to the significance of sustainability, there is a need to include it in software engineering and practice. Yet there is little guidance on which subjects and courses should be included and how. Becker et al. [5] also suggested the need for building competences in the theory and practice of sustainable design into the training of all software engineers. Sustainability has the potential to attract more students due to its indispensable significance for the future [29]. They also stressed that researchers and educators should develop improved curricula that include sustainability principles. Therefore, this paper contributes to the inclusion of a sustainability component in the body of knowledge on informatics education.

The remaining paper is organized as follows: in Section 2, related work with sustainability and sustainable informatics is presented; afterwards, Section 3 describes methodology; Section 4 introduces the curricula development on sustainable informatics; and Section 5 includes points of discussion, followed by the conclusion along with future research directions.

\section{Related Work}

Chowdhury and Koya [9] conducted a thematic analysis of four key UN policy documents related to sustainable development and argued that alongside financial and other resources, access to, and use of, appropriate information is essential for achieving sustainable development goals. The emphasis on sustainability has significant implications for information systems (IS) because such a move will result in a new set of organizational strategies and an accompanied challenge to IS units to create a new class of systems to support the execution of those strategies [30]. Nathan [31] defines sustainable information practices as the socially negotiated behavior through which we create, change, share, and store information. Paul and Aithal [32] emphasized on the need for domain centric information science programs i.e., Bio Informatics, Health Informatics, and Chem Informatics, for the sustainable development in different sectors such as biological, health, and chemical sectors.

Multiple studies have found that major challenges in the incorporation of sustainability in university education are in the field of teaching [23,33-35]. In this regard, Mann et al. [36] presented a framework for educators to design sustainability-centered education while Sammalisto and Lindhqvist [37] observed the integration of sustainability in higher education based on different sustainability dimensions such as environmental, economic, social and/or cultural. In this respect, identifying key competencies in sustainability can be the first step towards sustainability inclusion in higher education.

Wiek et al. [38] define competence as functionally linked complexes of knowledge, skills, and attitudes that enable successful task performance and problem solving. Competence is a quality developed through practice and not an end state [39]. Competencies capture the sense not only of acquiring but also of producing knowledge, embracing different ways of knowing, and avoiding a narrow focus on specific skills [40].

Several studies [41-43] have discussed the key competence in sustainability using different settings and models but with similar characteristics [44]. Barth et al. [45] analyzed the implications of new ways 
for both formal and informal learning settings for developing key competencies in sustainability within higher education with particular attention given to interdisciplinarity and students' self-responsibility. Wiek et al. [38] presented a framework of key competencies in sustainability for academic program development which lays the groundwork for institutional advancements in designing and revising academic programs; teaching and learning evaluations; as well as hiring and training faculty and staff. Giangrande et al. [46] modified it further by consolidating existing competency models with the addition of intrapersonal competency, a self-reflective validation scheme, and aligning it with sustainable development goals (SDG) 4.7 requirements.

Nolin [4] argued that integrating sustainable development into educational programs for information professionals actually could make us think harder about the role of information ethics in our educational programs. In this regard, Chowdhury and Koya [9] identified four key areas of teaching and research that can promote sustainability in information science: sustainable infrastructure and information systems; sustainable information practices; sustainable information policies and governance; and sustainable user education, training, and literacy [9].

There are some initiatives for introducing sustainability as individual courses in computing or the informatics curriculum. Caetano et al. [47] reported their experience in teaching their first Engineering for Sustainable Development (E4SD) summer course in a multicultural environment by using a problem-based learning approach in order to provide education in the sustainability aspects of the engineering professional activity. Aktas et al. [48] developed and implemented a novel interdisciplinary team-taught university-wide freshman course on the topic of sustainability and found it challenging to integrate five disciplines having significant differences in training and interests. Issa et al. [49] communicated the development and delivery of a new course dealing with the significance of sustainability and green IT to spread awareness of sustainable computing among information systems master's students at an Australian university. Worthington [50] reported on an online graduate level sustainable ICT Course at an Australian university, later adapted for North America by a Canadian university with industry-based participants from both private and public sector organizations, as well as full time university students. Furthermore, von Blottnitz et al. [24] reported on a curriculum reform process in an under-graduate chemical engineering program at the University of Cape Town to incorporate a focus on sustainable development. Miguel et al. [21] assessed the KPSS that should be developed by using a serious game called "the Island" to improve the degree of student satisfaction with the incorporation of sustainable curricula. Penzenstadler et al. [28] presented a design of an interdisciplinary intensive summer school course on software engineering for sustainability targeted for students with mixed backgrounds.

An exploratory investigation of 25 Spanish universities on how sustainability competences are being integrated into the study program found that there is a lack of environmental issues in the informatics engineering curriculum as well as no systematic and strategic integration along the degree programs [51]. Lambrechts et al. [44] analyzed study programs within two Belgian universities in the fields of business management, office management, and applied information technology and found that competences for sustainable development (SD) could be discovered within the selected study programs, though in an implicit and fragmented way, thus not covering all necessary fields of knowledge, skills, and attitudes. An analysis of existing degree programs showed that the majority of programs integrate sustainability in the information and communication technologies curriculum by providing separate green computing or environmental informatics courses, and only a few ones redesign traditional courses to make sustainability content a priority [52]. This calls for an adjustment of the study programs to clearly and explicitly integrate competences for SD [44]. More research is needed on the link between the integration of SD in competences, and the actual integration within the curriculum [44]. Sammalisto and Lindhqvist [37] suggested the idea of integration by linking the concept of sustainability to a particular field of study rather than separate courses. The curricula must include a significant number of compulsory courses where sustainability competences are 
embedded [34,53-55]. Further, competences for SD will expand and mature throughout the years, demanding a constant review and revision.

The latest ACM/IEEE curriculum guidelines for information technology professionals asserts that it would be useful to have students explore the role of an IT professional to discuss IT strategies needed in developing a culture of green computing and sustainability [56]. Awareness of these issues is important in developing a well-rounded and social conscious information technologist [56]. However, universities are still far from achieving an orientation of the curricula towards sustainable development [51,57] and the pace of change has been little and slow [58]. There is little strategic and systemic integration of sustainability into the curricula $[59,60]$. There is a need to include sustainability in informatics curricula in a systematic way. Therefore, this paper advances effort in this direction.

\section{Methodology}

Sammalisto and Lindhqvist [37] suggested that sustainability knowledge should be integrated by linking the concept of sustainability to a particular field of study rather than separate courses. Therefore, ACM/IEEE guidelines for IT curriculum development have been followed to list the courses IT graduates should take in order to practice their profession successfully. ACM/IEEE guidelines 2017 for IT curriculum development [56] consist of a set of IT competencies that students should learn, enable educational institutions to develop IT curricula that meet the growing demands of the changing technological world, and are useful for both industry and academia.

Further, an extensive literature survey is conducted in order to understand the knowledge and skills required by IT graduates in order to practice and realize sustainability in their profession. The information gained from the literature review along with authors' long academic experience in the IT discipline facilitates the inclusion of sustainability competence in the form of flexible units within existing courses of IT curricula. Finally, these courses are categorized into groups: fundamental, core, technical electives, non-technical electives, project-based courses, and industrial practice, based on the structure of academic programs in major universities.

It is crucial to assess whether units included in key courses of the IT curriculum provide knowledge and skills related with sustainability. Introducing key competencies for SD can be seen as an important step in the integration of sustainability in higher education [44]. Some significant studies describing key competencies in sustainability are $[38,42,43,45,46]$. Table 1 presents the way key competencies described in various frameworks maps with each other.

Table 1. Key competencies in sustainability as described in major studies.

\begin{tabular}{|c|c|c|c|c|}
\hline Barth et al. [45] & Sleurs [42] & Roorda [43] & Wiek et al. [38] & $\begin{array}{l}\text { Giangrande } \\
\text { et al. [46] }\end{array}$ \\
\hline $\begin{array}{l}\text { self-motivation; capacity for } \\
\text { empathy, compassion and } \\
\text { solidarity; reflection on individual }\end{array}$ & $\begin{array}{l}\text { Values and ethics; } \\
\text { knowledge }\end{array}$ & $\begin{array}{l}\text { responsibility; } \\
\text { personal } \\
\text { involvement }\end{array}$ & & Intrapersonal \\
\hline $\begin{array}{l}\text { motivating others; } \\
\text { Participatory skills }\end{array}$ & Emotions & $\begin{array}{l}\text { Emotional } \\
\text { intelligence }\end{array}$ & Interpersonal & Interpersonal \\
\hline \multirow[t]{2}{*}{ Foresighted thinking } & & future orientation & Anticipatory & Future thinking \\
\hline & System thinking & system orientation & $\begin{array}{l}\text { Systemic } \\
\text { working }\end{array}$ & $\begin{array}{l}\text { Systems } \\
\text { thinking }\end{array}$ \\
\hline Interdisciplinary work & & & & $\begin{array}{l}\text { Disciplinary } \\
\text { and } \\
\text { interdisciplinary }\end{array}$ \\
\hline $\begin{array}{l}\text { Cosmopolitan perception, } \\
\text { transcultural understanding and } \\
\text { co-operation; reflection on } \\
\text { cultural models }\end{array}$ & Emotions & $\begin{array}{l}\text { Emotional } \\
\text { intelligence }\end{array}$ & Normative & $\begin{array}{l}\text { Normative and } \\
\text { cultural }\end{array}$ \\
\hline Planning and implementation & Action & Action skills & Strategic & Strategic \\
\hline
\end{tabular}


Wiek et al. [38] proposed a framework of key competencies in sustainability by categorizing competencies into clusters. Giangrande et al. [46] found this to be a useful approach to enable contextualization, as well as the development of specific competencies, and further extended the framework. The present study follows the same approach and assesses proposed units based on existing frameworks $[38,46]$.

\section{Sustainability Oriented Informatics Curricula Outline}

The curriculum should include conceptual education and practice in IT and informatics courses so that students can get exposure to different components of sustainability issues. The word sustainable has appeared three times in IT 2017 guidelines, while green computing is mentioned nine times along with green IT two times [56]. It shows that there is a need to inculcate these in curricula so that future IT professionals can plan and develop sustainable and eco-friendly approaches in practice of the IT sector. Sustainable IT includes green IT requirements, product lifecycle guidelines, and equipment policies that constitute technology environments, namely: hardware, software, telecommunications, and people [61]. Figure 1 shows an approach to integrate sustainability education in informatics curricula.

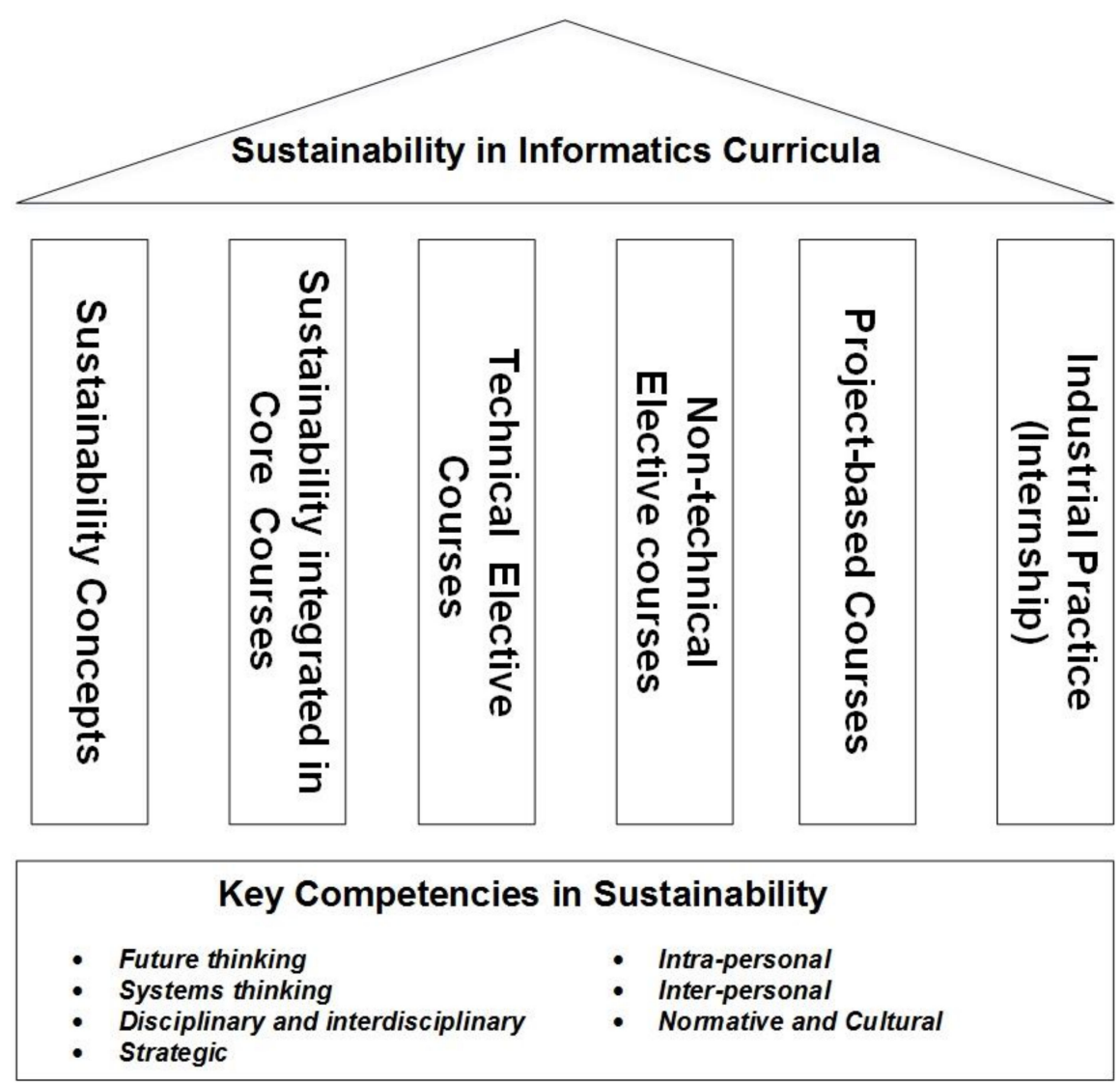

Figure 1. An approach for sustainability inclusion in Informatics Curricula.

The following describes the units that can be included in the existing courses e.g., sustainability theory can be introduced in a course that provides the fundamentals of IT. Most of these courses outlined here are in line with ACM/IEEE guidelines 2017 for Information Technology [56] curriculum development. These units are flexible in nature and inclusion of these in specified courses will provide sustainability theory, concepts, and application areas in the informatics/information technology discipline. 


\subsection{Sustainability Theory}

Understanding the concept of sustainability and eco-informatics and its different components, is important so as to be practiced to different stages of design, development, operations, and maintenance of information systems in different domains.

\subsection{Sustainability Requirements and Analysis}

Requirements are the key leverage point for practitioners who want to develop sustainable software intensive systems [5]. Sustainability must be treated as an important quality attribute similar to safety, security, efficiency, reliability, and usability [6]. Sustainability inclusion in requirements elicitation and analysis processes, necessitates the understanding of sustainability to apply in the requirements elicitation process which includes stakeholder modelling, goal modelling, process modelling, and system modelling. During requirements elicitation the teams may employ participatory techniques and requirements can be documented ensuing templates from IEEE Standard 8.30 [5] requirements specification. Similarly necessary, is the understanding of comprehensive analysis of sustainability issues in information system development, from project management (cost, schedule, staff), and process development. It should include, in general, information systems to be developed from an overall perspective to sustainability and long-term repercussion on sustainability.

\subsection{Sustainability Issues in Information System Design}

How to apply sustainability in different kinds of information system architecture and design issues, i.e., database, human computer interaction, and modules interface, structure chart, and in software architecture design evolution. In this context it is significant to note that standards are being adjusted, for instance, working group WG42 on ISO/IEC 42,030 (Architecture Evaluation) has considered energy efficiency and environmental concerns at the software architecture level and IEEE P1680.1 Standard for Environmental Assessment and Personal Computer Products is being updated [5].

\subsection{Information Systems Development and Management}

Selection of sustainable eco-oriented platform-based information system development, choice of right tools, management approaches toward sustainability and green IT based information systems. Sustainability issues should be included in information system process models and their related activities. It also consists of information system deployment, operations and maintenance keeping in view eco or green IT perspective.

\subsection{Ensuring Sustainable Testing and Quality Assurance}

Applying the right approach in ensuring sustainability in the process including quality and operation of the software product. Knowledge of standards of eco-design (ISO 14006, ISO 14062), software standard ISO/IEC 25010, Green computing standards. Testing for energy efficiency, much like security, performance, stability etc. [62]

\subsection{Sustainability Oriented Informatics Process Management}

Information system process development, deployment should include a sustainable information system process, an Agile, Lean, and DevOps software development paradigm. Further necessary is the knowledge of relevant tools, processes, and technologies to facilitate the sustainable information system development process. Energy and resources application are the main factors that influence sustainability. It includes the planning phase, monitoring stage of sustainability activities, along with sustainability policies, to ensure an efficient information system development and deployment process. Eco-design of digital services towards ensuring reducing environmental impacts to develop digital services that are more sustainable consume fewer resources and energy and produce less waste. 


\subsection{Sustainability Oriented Human Computer Interaction}

Human Computer Interaction (HCI) is part of many IT and software applications. Therefore, sustainability issues should be included as components in this course. Nyström and Mustaquim [63] supported that the persuasive system design can influence users to behave and live more sustainably and should be related to sustainability of the environment. Sustainable HCI should address WCED's (World Commission on Environment and Development) sustainability view " ... that it meets the needs of the present without compromising the ability of future generations to meet their own needs" [1]. Sustainable system design principles can be included in HCI, information system design, and the industrial project curriculum.

\subsection{Sustainable System Simulation and Modelling}

Requirements modelling contributes towards the realization of how to include sustainability issues in information systems with help from simulation models and tools. It also includes IS modelling by applying frameworks and tools for complex systems.

\subsection{Web and Mobile Systems}

Sustainability and page speed are correlated. When your website runs more efficiently it requires less processing power, thus less energy, and a lower carbon footprint [64]. Furthermore, sustainable design is efficient and accessible. Sustainable mobile apps and its users may contribute towards environmental goals and mobile devices are an enabler for sustainable actions due to their huge potential for scalability [65]. Mobile applications that have even a little effect on resource efficiency or the reduction of greenhouse gas emissions could result in a greater impact as these are used in daily life [65]. This can include concepts on social software interfaces with sustainability issues, green software development and usage practices, the promotion of technologies, and development frameworks and tools which facilitate sustainability in web and mobile systems' development. These could be included as real-life projects, cases studies, seminars, and lectures from industry practitioners.

\subsection{Sustainable Data Center}

Green data centers, or sustainable data centers as they will help in reducing carbon footprint, design and deploy data stores and applications to operate in energy-efficient ways. Therefore, they should include real life case studies, seminars, and discussions about how sustainability can be incorporated in data centers.

\subsection{Internet of Things (IoT)}

IoT has the ability to combat climate change towards the green environment. It could impact the sustainability in different areas such as use of water and energy efficiency. According to World Economic Forum, IoT could be a game changer for sustainability [66]. IoT helps in applying waste management strategies and in the circular economy. IoT deployments can help in addressing many SDGs of the UN. IoT technology can have tangible benefits to sustainability [66]. Many IoT initiatives may lead to the accomplishment of sustainability in the future [67]. Hence, students should be aware of such IoT applications which can apply to achieve sustainability as cases studies, white paper, discussions, seminars, etc.

\subsection{Sustainable Cloud Computing}

Cloud computing provides a more efficient use of computing power and is advantageous for environmental sustainability. The application of cloud computing facilitates towards ensuring social, business, and environmental sustainability. It can include discussions, case studies, seminars, projects, company visits, etc. 


\subsection{Virtual Systems and Services}

Virtual systems facilitate the use of fewer resources and provide the infrastructure to meet up with today's, and future, requirements. It includes concepts on how Network Virtualization, Storage Virtualization (Block virtualization and File virtualization), and Server virtualization can facilitate sustainability.

\subsection{Global Professional Practice/Social Responsibility}

Global professional practice should include environmental issues related with IT adoption and how the carbon footprint, $\mathrm{CO} 2$ emissions, and global warming are matters of concern. Students should be aware of these issues and their consequences for society. It should also include ethical, legal, privacy, intellectual, and professional issues so future IT professional will have this information to handle tasks in the best manner in IT governance and resource management. These can be included as case studies, seminars, and group discussions to analyze environmental degradation cases and towards exploring mitigation plans, identifying global environmental challenges, sustainable computing, energy management, and green computing standards in the context of IT applications. Thus, students should be able to analyze green IT policies, learn to identify green IT applications, and uses of green computing for improving energy efficiency.

\subsection{Sustainability Related Applications}

Identifying sustainability related challenges in the IT/informatics discipline, Apps for sustainability, sustainability assessment and management tools, and sustainability decision strategy support tools.

\subsection{Sustainability Oriented Industrial Projects}

Projects involving sustainability in IT/informatics applications during final years and internships, or such similar projects, as part of the course to provide real life inclusion of sustainability in IT/informatics discipline.

Table 2 classifies above mentioned units integrated in existing IT courses into major categories of courses based on the structure of academic programs in major universities.

Table 2. Classification of various units among major categories of courses.

\begin{tabular}{|c|c|}
\hline Foundation Courses & $\begin{array}{l}\text { These courses seek to develop the necessary foundational } \\
\text { knowledge and skills to prepare students for later courses in } \\
\text { the program [56]. Inclusion of a unit } 4.1 \text { will equip students } \\
\text { with basic know-how regarding sustainability in the context } \\
\text { of their discipline. }\end{array}$ \\
\hline $\begin{array}{l}\text { Core courses infused with } \\
\text { sustainability aspect }\end{array}$ & $\begin{array}{l}\text { Core courses addresses all required Knowledge Areas (KA) } \\
\text { of informatics. These courses will provide students exposure } \\
\text { towards application of sustainability in a particular } \\
\text { knowledge area. Above mentioned units such as } 4.2,4.3,4.4 \text {, } \\
4.5,4.6 \text { describe inclusion of sustainability issues in some of } \\
\text { the core KAs. }\end{array}$ \\
\hline Technical Electives & $\begin{array}{l}\text { Technical electives provide advanced technological } \\
\text { knowledge and skills in depth in a specific area of } \\
\text { informatics. Example units } 4.7,4.8,4.9,4.10,4.11,4.12,4.13 \\
\text { show the integration of sustainability dimension in technical } \\
\text { electives courses. }\end{array}$ \\
\hline
\end{tabular}


Table 2. Cont.

An informatics professional must possess non-technical skills, also known as professional/soft skills in order to succeed in the work force. Industry managers emphasize

Non-technical Electives that non-technical and technical skills have equal or similar value while hiring a fresh graduate [56]. There are various non-technical electives offered to students in informatics study program and sustainability can be integrated in such courses or offered separately such as unit 4.14 .

Project-based courses assist students to acquire practical and deeper knowledge through active exploration of real-world

Project-based courses challenges and problems. Embracing details given in unit 4.15 will contribute towards managing challenges associated with sustainability.

Industry internships provide students an opportunity to closely experience the working of actual workplace and

Industry internship enhance their practical experience. An example unit 4.16 can provide an opportunity for real world experience by including sustainability as a learning outcome in industrial practice courses.

Further, Table 3 depicts how integration of these units into current curriculum will help IT professionals to acquire key competencies in sustainability.

Table 3. Assessment of key competence in sustainability for proposed units in IT curriculum.

\begin{tabular}{|c|c|c|c|c|c|c|c|}
\hline \multirow[b]{2}{*}{ Units } & \multicolumn{7}{|c|}{ Key Competencies in Sustainability $[38,46]$} \\
\hline & $\begin{array}{c}\text { Intra- } \\
\text { Personal }\end{array}$ & $\begin{array}{c}\text { Inter- } \\
\text { Personal }\end{array}$ & $\begin{array}{l}\text { Future } \\
\text { Thinking }\end{array}$ & $\begin{array}{l}\text { Systems } \\
\text { Thinking }\end{array}$ & $\begin{array}{l}\text { Disciplinary } \\
\text { and } \\
\text { Interdisciplinary }\end{array}$ & $\begin{array}{l}\text { Normative } \\
\text { and } \\
\text { Cultural }\end{array}$ & Strategic \\
\hline Sustainability theory & $x$ & & $x$ & $x$ & $x$ & & $x$ \\
\hline $\begin{array}{l}\text { Sustainability } \\
\text { Requirements and } \\
\text { Analysis }\end{array}$ & $\mathrm{X}$ & $\mathrm{X}$ & $\mathrm{X}$ & $x$ & $x$ & & $x$ \\
\hline $\begin{array}{l}\text { Sustainability issues } \\
\text { in Information } \\
\text { System Design }\end{array}$ & & $x$ & $\mathrm{x}$ & $\mathrm{x}$ & $x$ & & $x$ \\
\hline $\begin{array}{l}\text { Information Systems } \\
\text { Development and } \\
\text { Management }\end{array}$ & & $\mathrm{x}$ & $\mathrm{x}$ & $\mathrm{X}$ & $x$ & & $x$ \\
\hline $\begin{array}{l}\text { Sustainable Testing } \\
\text { and Quality } \\
\text { Assurance }\end{array}$ & $\mathrm{x}$ & $x$ & $x$ & $x$ & & & $x$ \\
\hline $\begin{array}{l}\text { Sustainability } \\
\text { oriented Informatics } \\
\text { Process Management }\end{array}$ & & $x$ & $x$ & $X$ & $x$ & & $x$ \\
\hline $\begin{array}{l}\text { Sustainability } \\
\text { Oriented Human } \\
\text { Computer Interaction }\end{array}$ & & $x$ & $x$ & $\mathrm{X}$ & $\mathrm{X}$ & $\mathrm{X}$ & $\mathrm{X}$ \\
\hline $\begin{array}{l}\text { Sustainable System } \\
\text { Simulation and } \\
\text { Modelling }\end{array}$ & & & $\mathrm{x}$ & $\mathrm{x}$ & & & $x$ \\
\hline $\begin{array}{l}\text { Web and Mobile } \\
\text { Systems }\end{array}$ & & $\mathrm{X}$ & $\mathrm{x}$ & $x$ & $x$ & & $x$ \\
\hline
\end{tabular}


Table 3. Cont.

\begin{tabular}{|c|c|c|c|c|c|c|c|}
\hline \multirow[b]{2}{*}{ Units } & \multicolumn{7}{|c|}{ Key Competencies in Sustainability $[38,46]$} \\
\hline & $\begin{array}{l}\text { Intra- } \\
\text { Personal }\end{array}$ & $\begin{array}{c}\text { Inter- } \\
\text { Personal }\end{array}$ & $\begin{array}{l}\text { Future } \\
\text { Thinking }\end{array}$ & $\begin{array}{l}\text { Systems } \\
\text { Thinking }\end{array}$ & $\begin{array}{l}\text { Disciplinary } \\
\text { and } \\
\text { Interdisciplinary }\end{array}$ & $\begin{array}{l}\text { Normative } \\
\text { and } \\
\text { Cultural }\end{array}$ & Strategic \\
\hline $\begin{array}{l}\text { Sustainable Data } \\
\text { Center }\end{array}$ & & & $\mathrm{x}$ & $x$ & & & $x$ \\
\hline $\begin{array}{l}\text { Internet of Things } \\
\text { (IoT) }\end{array}$ & & & $\mathrm{x}$ & $x$ & $x$ & & $x$ \\
\hline $\begin{array}{l}\text { Sustainable Cloud } \\
\text { Computing }\end{array}$ & & & $x$ & $x$ & $x$ & & $x$ \\
\hline $\begin{array}{l}\text { Virtual Systems and } \\
\text { Services }\end{array}$ & & & $x$ & $x$ & & & $\mathrm{X}$ \\
\hline $\begin{array}{l}\text { Global Professional } \\
\text { Practice/Social } \\
\text { Responsibility }\end{array}$ & $x$ & $x$ & $x$ & $\mathrm{X}$ & $x$ & $x$ & $x$ \\
\hline $\begin{array}{l}\text { Sustainability Related } \\
\text { Applications }\end{array}$ & & & & $x$ & $x$ & & $x$ \\
\hline $\begin{array}{l}\text { Sustainability } \\
\text { Oriented Industrial } \\
\text { Projects }\end{array}$ & & $x$ & $x$ & & $x$ & $x$ & $x$ \\
\hline
\end{tabular}

\section{Discussion}

The United Nations Agenda 2030 for sustainable development consists of 17 Sustainable Development Goals (SDGs) and 169 associated targets [68]. One of the targets, 4.7, is:

"by 2030, ensure all learners acquire knowledge and skills needed to promote sustainable development, including, among others, through education for sustainable development and sustainable lifestyles, human rights, ..."

Education is the key that can help to deliver these goals and targets. Pernici et al. [69] probed the key question: what is the curriculum of sustainability training? Another issue brought forward is that sustainability training should refrain from introducing new content or new modules in the curricula, which in general are already very overloaded [33,34]. Instead there is a need to integrate sustainability, and environmental literacy more broadly, into all programs, curricula, and syllabi, from freshmen to $\mathrm{PhD}$ students, regardless of discipline, and to strengthen adequate career paths [7]. Inclusion of the sustainability aspect to existing courses will also help in the application of sustainability knowledge in the context of the course.

Sustainability is becoming an essential competence across different engineering disciplines [47]. ACM/IEEE curriculum guidelines for information technology degree programs have also specified sustainability under essential as well as supplemental knowledge areas [56]. It involves development and use of technologies, tools, standards, methods, regulations, policies, and practices, as well as human and social/institutional behavior so that sustainability can be achieved throughout the lifecycle of data and information [9]. It is also important to provide education in the sustainability aspects of engineering professional activity such as engineering for a sustainable society, decision analysis for sustainability, sustainable product design, materials and process for sustainable engineering, sustainability in project management, etc. [47]

In the preceding section, various units have been proposed that can integrate sustainability aspects into existing courses, according to the ACM/IEEE guidelines for IT curricula, and categorized under six main pillars (see Table 1), namely, foundation courses; core courses; technical electives; non-technical electives; project-based courses; and industry internship.

Foundation courses on sustainable development will equip students of informatics programs with the basic know how of theory, principles, and practices of sustainability relevant to their discipline. 
Basic knowledge on sustainability for every engineer linked to the engineers' social responsibility is imperative [33].

It must be ensured that actions that involve the development of sustainability competences reach to all students [51]. Therefore, the curricula must include a significant number of compulsory core courses where sustainability competences are embedded [34,53-55]. The integration of sustainability in core courses such as requirements gathering and analysis, information system design, development, management, testing, and quality assurance, will help students to apply sustainability concepts within the context of core courses, for example, requirement elicitation and analysis with respect to informatics is the process of gathering, analyzing, and defining requirements with the help of customers and other stakeholders. Sustainability comes under non-functional requirements [70]. A software system's influence on its environment is often determined by how the software professionals understand its requirements [5]. Sustainability inclusion in requirements elicitation and analysis processes, will lead to gathering and defining sustainability requirements in order to achieve different dimensions of sustainability and reduce long-term repercussions on the environment and society. The key to induce sustainability through software is in treating sustainability as an integral concern in requirements engineering [5]. It is due to the fact that the impact that a software system will have in its (individual, social, economic, and technical, environmental) environment is mainly determined by how software professionals set out the software requirements. During the risk analysis, the team looks upon internal and external risks related to systemic effects in all five dimensions, and resulting requirements specification is based on a template that includes checklists for sustainability criteria and standard compliance in all five decisions [5].

Becker et al. [71] in their studies observed that all software design professionals require the involvement of sustainability design. They further argued it was meant for a mixed population of software professionals including HCI professionals. Successful collaborations to assimilate sustainability concerns into established practices can significantly and positively affect the long-term effects of the system design [5]. They further argued, for instance, that the system can support sustainability in the supply chain by composing transparent carbon footprints of purchases and facilitating the choice of providers who apply sustainable practices. Software architecture sustainability indicates to the ability of the architecture to endure changes arisen from shifts in requirements, environment, technologies, business strategies, and goals throughout software system life cycles [72,73]. They observed that architecture sustainability is the capacity of a software architecture to endure various types of change through efficient maintenance and systematic evolution over its complete lifecycle.

Technical electives (e.g., simulation and modeling, cloud computing, virtual systems and services) and non-technical electives (e.g., global professional practice, social responsibility) provide students with in-depth technical knowledge/skills of relevant topics and soft skills necessary for their professional life, respectively. Integration of sustainability in these courses will help university graduates to acquire sustainable development related competencies, for example, the potential of serious games to develop key professional skills for sustainability (KPSS) towards SDG has been confirmed [21]. It has been suggested that most sustainable development related competencies are developed through simulations $[41,74,75]$. Non-technical electives (e.g., global professional practice, social responsibilities) are conducive to giving a holistic view of sustainability [51].

Project-centered learning is best suited for building sustainable development into the engineering curriculum [24]; however, theoretical foundation needs to be explicitly taught alongside project work [24]. Industry internships will aid students with sustainability knowledge and skills through industry engagement.

The proposed curriculum development can be easily customized and included as part of an undergraduate- or graduate-level IT/informatics curriculum. Presently only a limited number of undergraduate and graduate programs on sustainability have been introduced in the last decade in certain institutions. Therefore, the curricula proposed here can be a useful addition to the literature and educators. Further, to provide sustainability exposure to students, workshops and conferences 
by experts, case studies, seminar presentations, debates, industry reports, and class discussions are highly recommended. There is need for connection with real-world problems by students and faculty members. In this context organizing events such as seminars, projects, quiz contests, competitions, and internship-learning, that address sustainability relevance, may get credit recognition as an incentive towards motivation.

Further, the proposed IT curriculum coupled with sustainability has been assessed using frameworks of key competencies in sustainability suggested by Wiek et al. [38] and Giangrande et al. [46] As can be seen from Table 3, most of the IT courses have the potential to provide proficiency in the majority of key competencies such as systems thinking, disciplinary and interdisciplinary, strategic, future thinking, and inter-personal. Lambrechts et al. [44] argued that integration of competencies linked with future orientation (future thinking), system orientation (systems thinking), personal involvement (intra-personal), and action skills (strategic) can substantially contribute to a truly integrative approach towards education for sustainable development. However, two of the key competencies, intra-personal as well as normative and cultural, have been covered in few of the proposed courses. Intra-personal competencies can be a challenge for educators and learners [46]. In order to change competencies into action, it is important for learners to understand their underlying values and motivational drivers [46].

\section{Conclusions}

Due to diffusion of IT in day-to-day life, along with challenges of sustainability, the commitment of future IT professionals is crucial. Therefore, it is significant that future IT professionals be trained with various sustainability issues in such a manner so that they will be able to include sustainability into practice later in their professional life. The present work describes the integration of important units of sustainability in the IT curriculum. The units' description provided is kept flexible so that teachers can decide on the level of detail and complexity in order to suit the courses based on the existing contents and course workload. It also includes appraisal of key competencies in sustainability for proposed units in the IT curriculum. This paper has contributed to the body of knowledge in this area by specifying how different units of sustainability can be easily included within existing courses according to recent ACM/IEEE curriculum guidelines for IT programs. This effort will also aid in developing a sustainable society geared towards the welfare of humankind. As others, this study has few limitations, for instance, it is based on recent IEEE/ACM guidelines for the IT curriculum. This proposal is yet to be implemented in Universities/Institutions. Once implemented, it can be revised and further improved based on students' feedback. As a future research direction, it would be interesting to compare the inclusion of sustainability in the IT curriculum in various Universities in different countries. Further, different modes of teaching and assessment for these courses can be explored.

Author Contributions: Conceptualization, D.M. and A.M.; Formal analysis, D.M. and A.M.; Methodology, D.M. and A.M.; Writing—original draft, D.M. and A.M.; Writing-review and editing, D.M. and A.M. All authors have read and agreed to the published version of the manuscript.

Funding: The APC was funded by NTNU—Norwegian University of Science and Technology, Norway.

Conflicts of Interest: The authors declare no conflict of interest.

\section{References}

1. Brundtland Commission. Report of the World Commission on Environment and Development: Our Common Future; United Nations: New York, NY, USA, 1987; Volume 10, p. 300.

2. Goodland, R. Sustainability: Human, social, economic and environmental. Encycl. Glob. Environ. Change 2002, 5, 481-491.

3. Brooks, S.; Wang, X.; Sarker, S. Unpacking green IS: A review of the existing literature and directions for the future. In Green Business Process Management; Springer: Berlin/Heidelberg, Germany, 2012; pp. 15-37.

4. Nolin, J. Sustainable information and information science. Inf. Res. 2010, 15, 15. 
5. Becker, C.; Betz, S.; Chitchyan, R.; Duboc, L.; Easterbrook, S.M.; Penzenstadler, B.; Seyff, N.; Venters, C.C. Requirements: The key to sustainability. IEEE Softw. 2015, 33, 56-65. [CrossRef]

6. Penzenstadler, B.; Raturi, A.; Richardson, D.; Tomlinson, B. Safety, security, now sustainability: The nonfunctional requirement for the 21st century. IEEE Softw. 2014, 31, 40-47. [CrossRef]

7. UNESCO. Guidelines on Sustainability Science in Research and Education; UNESCO: London, UK, $2017 ;$ p. 9.

8. Meschede, C.; Henkel, M. Library and information science and sustainable development: A structured literature review. J. Doc. 2019. [CrossRef]

9. Chowdhury, G.; Koya, K. Information practices for sustainability: Role of iSchools in achieving the UN sustainable development goals (SDGs). J. Assoc. Inf. Sci. Technol. 2017, 68, 2128-2138. [CrossRef]

10. Mishra, A.; Akman, I. Green Information Technology (GIT) and gender diversity. Environ. Eng. Manag. J. 2014, 13. [CrossRef]

11. Chowdhury, G. Sustainability of digital information services. J. Doc. 2013. [CrossRef]

12. Fourman, M. Informatics. In International Encyclopedia of Information and Library Science; Routledge: Abingdon, UK, 2002.

13. Sverdrup, H.; Svensson, M.G. Defining the concept of sustainability-a matter of systems thinking and applied systems analysis. In Systems Approaches and their Application; Springer: Berlin/Heidelberg, Germany, 2004; pp. 143-164.

14. Harmon, R.; Demirkan, H.; Auseklis, N.; Reinoso, M. From green computing to sustainable IT: Developing a sustainable service orientation. In Proceedings of the 2010 43rd Hawaii International Conference on System Sciences, Honolulu, HI, USA, 5-8 January 2010; pp. 1-10.

15. Machado, M.C.; Hourneaux Junior, F.; Sobral, F.A. Sustainability in information technology: An analysis of the aspects considered in the model COBIT. JISTEM J. Inf. Syst. Technol. Manag. 2017, 14, 88-110. [CrossRef]

16. Shapiro, H.T. A Larger Sense of Purpose: Higher Education and Society; Princeton University Press: Princeton, NJ, USA, 2009; Volume 48.

17. Rieckmann, M. Education for Sustainable Development Goals: Learning Objectives; UNESCO Publishing: London, UK, 2017.

18. Lengthorn, E. Science education and the UN sustainable development goals. Educ. Sci. 2018, Issue 274, 2-4.

19. Glasser, H.; Hirsh, J. Toward the development of robust learning for sustainability core competencies. Sustain. J. Rec. 2016, 9, 121-134. [CrossRef]

20. Torre, D.; Procaccianti, G.; Fucci, D.; Lutovac, S.; Scanniello, G. On the presence of green and sustainable software engineering in higher education curricula. In Proceedings of the 2017 IEEE/ACM 1st International Workshop on Software Engineering Curricula for Millennials (SECM), Buenos Aires, Argentina, 27 May 2017; pp. 54-60.

21. Miguel, N.P.; Lage, J.C.; Galindez, A.M. Assessment of the Development of Professional Skills in University Students: Sustainability and Serious Games. Sustainability 2020, 12, 1014. [CrossRef]

22. Granados Sánchez, J.; Junyent i Pubill, M. Retos y oportunidades en la ambientalización curricular. Cuad. Pedagog. 2015, 460, 48-52.

23. Lazzarini, B.; Perez-Foguet, A.; Boni, A. Key characteristics of academics promoting Sustainable Human Development within engineering studies. J. Clean. Prod. 2018, 188, 237-252. [CrossRef]

24. Von Blottnitz, H.; Case, J.M.; Fraser, D.M. Sustainable development at the core of undergraduate engineering curriculum reform: A new introductory course in chemical engineering. J. Clean. Prod. 2015, 106, 300-307. [CrossRef]

25. Alexa, L.; Maier, V.; Serban, A.; Craciunescu, R. Engineers changing the world: education for sustainability in Romanian Technical Universities-An empirical web-based content analysis. Sustainability 2020, 12, 1983. [CrossRef]

26. Kurkovsky, A. Educational aspects of sustainable development analysis: Computational models and software. J. Comput. Sci. Coll. 2006, 21, 24-31.

27. Gibson, M.L.; Venters, C.; Duboc, L.; Betz, S.; Chitchyan, R.; Palacin Silva, V.; Penzenstadler, B.; Seyff, N. Mind the chasm: A UK fisheye lens view of sustainable software engineering. In Proceedings of the 6th International Workshop on Requirements Engineering for Sustainable Systems, Lisbon, Portugal, 4 September 2017; pp. 15-24. 
28. Penzenstadler, B.; Betz, S.; Venters, C.C.; Chitchyan, R.; Porras, J.; Seyff, N.; Duboc, L.; Becker, C. Everything is INTERRELATED: Teaching software engineering for sustainability. In Proceedings of the 2018 IEEE/ACM 40th International Conference on Software Engineering: Software Engineering Education and Training (ICSE-SEET), Gothenburg, Sweden, 25 May-3 June 2018; pp. 153-162.

29. Özkan, B.; Mishra, A. A curriculum on sustainable information communication technology. Probl. Ekorozw. Probl. Sustain. Dev. 2015, 10, 95-101.

30. Watson, R.T.; Lind, M.; Haraldson, S. The emergence of sustainability as the new dominant logic: Implications for Information Systems. In Proceedings of the International Conference on Information Systems, Orlando, FL, USA, 16-19 December 2012; pp. 1747-1762.

31. Nathan, L.P. Sustainable information practice: An ethnographic investigation. J. Am. Soc. Inf. Sci. Technol. 2012, 63, 2254-2268. [CrossRef]

32. Paul, P.; Aithal, P. Higher Education and India: The need of Domain Centric Information Sciences for solid and Sustainable Development. In Proceedings of the National Conference on Advances in Information Technology, Management, Social Sciences and Education; SIMS Pandeshwar \& Srinivas University Mukka: Mangalore, India, 2018; pp. 19-26.

33. Mulder, K.F.; Segalàs, J.; Ferrer-Balas, D. How to educate engineers for/in sustainable development. Int. J. Sustain. High. Educ. 2012. [CrossRef]

34. Buckler, C.; Creech, H. Shaping the Future We Want: UN Decade of Education for Sustainable Development; Final Report; UNESCO: London, UK, 2014.

35. Wals, A.E. Sustainability in higher education in the context of the UN DESD: A review of learning and institutionalization processes. J. Clean. Prod. 2014, 62, 8-15. [CrossRef]

36. Mann, S.; Muller, L.; Davis, J.; Roda, C.; Young, A. Computing and sustainability: Evaluating resources for educators. ACM SIGCSE Bull. 2010, 41, 144-155. [CrossRef]

37. Sammalisto, K.; Lindhqvist, T. Integration of sustainability in higher education: A study with international perspectives. Innov. High. Educ. 2008, 32, 221-233. [CrossRef]

38. Wiek, A.; Withycombe, L.; Redman, C.L. Key competencies in sustainability: A reference framework for academic program development. Sustain. Sci. 2011, 6, 203-218. [CrossRef]

39. Vare, P.; Arro, G.; De Hamer, A.; Del Gobbo, G.; de Vries, G.; Farioli, F.; Kadji-Beltran, C.; Kangur, M.; Mayer, M.; Millican, R. Devising a competence-based training program for educators of sustainable development: Lessons learned. Sustainability 2019, 11, 1890. [CrossRef]

40. Hartmeyer, R.; Bølling, M.; Bentsen, P. Approaching multidimensional forms of knowledge through Personal Meaning Mapping in science integrating teaching outside the classroom. Instr. Sci. 2017, 45, 737-750. [CrossRef]

41. De Haan, G. The development of ESD-related competencies in supportive institutional frameworks. Int. Rev. Educ. 2010, 56, 315-328. [CrossRef]

42. Sleurs, W. Competencies for ESD (Education for Sustainable Development) Teachers. A Framework to Integrate ESD in the Curriculum of Teacher Training Institutes; CSCT Project (Comenius 2.1 project 118277-CP-1-2004-BE-Comenius-C2. 1); United Nations Economic Commission for Europe: Brussels, Belgium, 2008.

43. Roorda, N. Sailing on the Winds of Change: The Odyssey to Sustainability of the Universities of Applied Sciences in the Netherlands. Ph.D. Thesis, Maastricht University, Maastricht, The Netherlands, 2010.

44. Lambrechts, W.; Mulà, I.; Ceulemans, K.; Molderez, I.; Gaeremynck, V. The integration of competences for sustainable development in higher education: An analysis of bachelor programs in management. J. Clean. Prod. 2013, 48, 65-73. [CrossRef]

45. Barth, M.; Godemann, J.; Rieckmann, M.; Stoltenberg, U. Developing key competencies for sustainable development in higher education. Int. J. Sustain. High. Educ. 2007. [CrossRef]

46. Giangrande, N.; White, R.M.; East, M.; Jackson, R.; Clarke, T.; Saloff Coste, M.; Penha-Lopes, G. A competency framework to assess and activate education for sustainable development: Addressing the UN sustainable development goals 4.7 challenge. Sustainability 2019, 11, 2832. [CrossRef]

47. Caetano, N.; Rocha, J.; Quadrado, J.C.; Cardoso, J.M.; Felgueiras, M.C. Teaching sustainability in a multicultural environment. In Proceedings of the 3rd International Conference on Technological Ecosystems for Enhancing Multiculturality; Association for Computing Machinery: New York, NY, USA, 2015; pp. 145-150. 
48. Aktas, C.B.; Whelan, R.; Stoffer, H.; Todd, E.; Kern, C.L. Developing a university-wide course on sustainability: A critical evaluation of planning and implementation. J. Clean. Prod. 2015, 106, 216-221. [CrossRef]

49. Issa, T.; Issa, T.; Chang, V. Sustainability and green IT education: Practice for incorporating in the Australian higher education curriculum. Int. J. Sustain. Educ. 2014, 9, 19-30. [CrossRef]

50. Worthington, T. A Green computing professional education course online: Designing and delivering a course in ICT sustainability using Internet and eBooks. In Proceedings of the 2012 7th International Conference on Computer Science \& Education (ICCSE), Melbourne, Australia, 14-17 July 2012; pp. 263-266.

51. Rubio, R.M.; Uribe, D.; Moreno-Romero, A.; Yáñez, S. Embedding sustainability competences into engineering education. The case of informatics engineering and industrial engineering degree programs at Spanish universities. Sustainability 2019, 11, 1-29.

52. Klimova, A.; Rondeau, E. Education for cleaner production in information and communication technologies curriculum. IFAC Pap. 2017, 50, 12931-12937. [CrossRef]

53. De Wit, H.; Leask, B. Reimagining the Curriculum for the 21st Century. Higher Educ. World 2017, 6, $222-235$.

54. Moreso, J.; Casadesús, M. Preparing the global citizenry, implications for the curriculum. Higher Educ. World 2017, 6, 181-193.

55. Rathje, D.; Spitzer, H.; Zandvoort, H. How to prepare students for a responsible use of science and engineering. In Proceedings of the Workshop 'Teaching Ethics and Peace to Science and Engineering Students', Hamburg, Germany, 15-17 October 2008; pp. 1-12.

56. Sabin, M.; Alrumaih, H.; Impagliazzo, J.; Lunt, B.; Zhang, M.; Byers, B.; Newhouse, W.; Paterson, B.; Peltsverger, S.; Tang, C. Information Technology Curricula 2017: Curriculum Guidelines for Baccalaureate Degree Programs in Information Technology; Technical Report; Association for Computing Machinery (ACM): New York, NY, USA, 2017. [CrossRef]

57. Mulder, K.F.; Ferrer, D.; Coral, J.S.; Kordas, O.; Nikiforovich, E.; Pereverza, K. Motivating students and lecturers for education in sustainable development. Int. J. Sustain. High. Educ. 2015. [CrossRef]

58. Watson, M.K.; Lozano, R.; Noyes, C.; Rodgers, M. Assessing curricula contribution to sustainability more holistically: Experiences from the integration of curricula assessment and students' perceptions at the Georgia Institute of Technology. J. Clean. Prod. 2013, 61, 106-116. [CrossRef]

59. Allen, D.; Allenby, B.; Bridges, M.; Crittenden, J.; Davidson, C.; Hendrickson, C.; Matthews, S.; Murphy, C.; Pijawka, D. Benchmarking Sustainability Engineering Education; Final Report EPA Grant X3-83235101; University of Texas: Austin, TX, USA, 2008.

60. Byrne, E.P.; Desha, C.J.; Fitzpatrick, J.J. Exploring sustainability themes in engineering accreditation and curricula. Int. J. Sustain. High. Educ. 2013. [CrossRef]

61. Standing, C.; Jackson, P. An approach to sustainability for information systems. J. Syst. Inf. Technol. 2007. [CrossRef]

62. Mishra, A.; Mishra, D. Sustainable Software Engineering Education Curricula Development. Int. J. Inf. Technol. Secur. 2020, 12, 47-56.

63. Nyström, T.; Mustaquim, M.M. Sustainable information system design and the role of sustainable HCI. In Proceedings of the 18th International Academic MindTrek Conference: Media Business, Management, Content $\mathcal{E}$ Services; Springer: Cham, Switzerland, 2014; pp. 66-73.

64. The Building Blocks of Sustainable Web Design. Available online: https://sustainablewebdesign.org/ (accessed on 3 March 2020).

65. Brauer, B.; Ebermann, C.; Hildebrandt, B.; Remané, G.; Kolbe, L.M. Green by app: The contribution of mobile applications to environmental sustainability. In Proceedings of the Pacific Asia Conference on Information Systems (PACIS); Association for Information System: Atlanta, GA, USA, 2016.

66. Arias, R.; Lueth, K.; Rastogi, A. The effect of the Internet of Things on sustainability. In Proceedings of World Economic Forum. Available online: https://www.weforum.org/agenda/2018/01/effect-technologysustainability-sdgs-internet-thingsiot (accessed on 14 March 2019).

67. Lazarevich, K. 10 IoT Initiatives for a More Sustainable Future. 2018. Available online: https://www.iotforall. com/10-iot-environment-initiatives-sustainable-future/ (accessed on 16 March 2020).

68. United Nations. Sustainable Development Knowledge Platform. 2015. Available online: https://sdgs.un.org/ goals (accessed on 11 February 2019). 
69. Pernici, B.; Aiello, M.; vom Brocke, J.; Donnellan, B.; Gelenbe, E.; Kretsis, M. What IS can do for environmental sustainability: A report from CAiSE'11 panel on Green and sustainable IS. Commun. Assoc. Inf. Syst. 2012, 30, 18. [CrossRef]

70. Betz, S.; Caporale, T. Sustainable software system engineering. In Proceedings of the 2014 IEEE Fourth International Conference on Big Data and Cloud Computing, Sydney, Australia, 3-5 December 2014; pp. 612-619.

71. Becker, C.; Chitchyan, R.; Duboc, L.; Easterbrook, S.; Penzenstadler, B.; Seyff, N.; Venters, C.C. Sustainability design and software: The karlskrona manifesto. In Proceedings of the 2015 IEEE/ACM 37th IEEE International Conference on Software Engineering, Florence, Italy, 16-24 May 2015; pp. 467-476.

72. Avgeriou, P.; Stal, M.; Hilliard, R. Architecture sustainability [guest editors' introduction]. IEEE Softw. 2013, 30, 40-44. [CrossRef]

73. Kim, D.-K.; Ryoo, J.; Kim, S. Building sustainable software by preemptive architectural design using tactic-equipped patterns. In Proceedings of the 2014 Ninth International Conference on Availability, Reliability and Security, Fribourg, Switzerland, 8-12 September 2014; pp. 484-489.

74. Kagawa, F. Dissonance in students' perceptions of sustainable development and sustainability: Implications for curriculum change. Int. J. Sustain. High. Educ. 2007, 8, 317-338. [CrossRef]

75. Willemse, T.M.; ten Dam, G.; Geijsel, F.; van Wessum, L.; Volman, M. Fostering teachers' professional development for citizenship education. Teach. Teach. Educ. 2015, 49, 118-127. [CrossRef]

(C) 2020 by the authors. Licensee MDPI, Basel, Switzerland. This article is an open access article distributed under the terms and conditions of the Creative Commons Attribution (CC BY) license (http://creativecommons.org/licenses/by/4.0/). 